\title{
Effect of aluminum concentration on growth and secondary metabolites production in three chemotypes of Cunila galioides Benth. medicinal plant
}

\author{
Mossi, AJ. ${ }^{a *}$, Pauletti, GF. ${ }^{b}$ Rota, L. ${ }^{b}$, Echeverrigaray, S. ${ }^{b}$, Barros, IBI. ${ }^{c}$, \\ Oliveira, JV. ${ }^{a}$, Paroul, . $^{a}$ and Cansian, RL. ${ }^{a}$ \\ aDepartamento de Ciências Agrárias, Universidade Regional Integrada do Alto Uruguai e das Missões - URI, \\ Campus de Erechim, Av. 7 de Setembro, 1621, CEP 99700-000, Erechim, RS, Brazil \\ 'Instituto de Biotecnologia, Universidade de Caxias do Sul - UCS, \\ Av. Francisco Getúlio Vargas, 1130, CEP 95070-560, Caxias do Sul, RS, Brazil \\ 'Departamento de Horticultura e Silvicultura, Universidade Federal do Rio Grande do Sul - UFRGS, \\ Av. Bento Gonçalves, 7712, Porto Alegre, RS, CEP 90001-970, Brazil \\ *e-mail: cansian@uricer.edu.br
}

Received June 16, 2010 - Accepted October 4, 2011 - Distributed November 30, 2011

(With 3 figures)

\begin{abstract}
Medicine plants play an important role in public health, especially in developing countries, and among them Cunila galioides Benth. is a naturally occurring medicinal and aromatic plant native from south Brazil. Flavonoids, present in significant amounts in some species of Cunila sp., possess several properties and its content may be affected by aluminum stress. In this context, the aim of this work was to assess the influence of different levels of aluminum in nutrient solution on the growth and content of essential oils and flavonoids in three chemotypes of Cunila galioides. The plant parameters evaluated were aerial dry matter, dry root matter, root length, root score, calcium and aluminum concentrations in the vegetable tissue, flavonoids content as well as essential oil yield and its major components concentration. Results showed that the addition of $30.0 \mathrm{mg} . \mathrm{L}^{-1}$ of $\mathrm{Al}^{3+}$ to the nutrient solution leads to a decrease of all agronomic parameters evaluated with losses in the cultivation yield for the greatest concentration studied. The André da Rocha population was found to be the most tolerant to aluminum while Bom Jardim da Serra was the most sensitive. The aluminum concentration did not influence the extraction yield as well as the content of major components in the oils. The concentration of flavonoids increased significantly for the populations tolerant to aluminum concentration in the nutrient solution, thus indicating a relationship between tolerance and flavonoids production, which may be an interesting characteristic from the medicinal point of view.
\end{abstract}

Keywords: aluminum tolerance, hydroponics, medicinal plants, flavonoids.

\section{Efeito da concentração de alumínio no crescimento e produção de metabólitos secundários em três quimiotipos da planta medicinal Cunila galioides Benth}

\begin{abstract}
Resumo
Plantas medicinais desempenham um papel importante na saúde pública, especialmente em países em desenvolvimento, e entre elas Cunila galioides Benth., que é uma planta nativa de ocorrência no sul do Brasil. Os flavonoides, presentes em quantidades significativas em algumas espécies de Cunila sp., possuem diversas propriedades, sendo que seu teor pode ser afetado por estresse de alumínio. Neste contexto, o objetivo deste trabalho foi avaliar a influência de diferentes níveis de alumínio na solução nutritiva, em relação ao crescimento e teor de óleos essenciais e de flavonoides, em três quimiotipos de Cunila galioides Benth. Os parâmetros avaliados foram matéria seca da parte aérea, matéria seca da raiz, comprimento da raiz, contagem de raízes, concentrações de cálcio e alumínio no tecido vegetal, teor de flavonoides, assim como o rendimento do óleo essencial e concentração dos seus componentes principais. Os resultados mostraram que a adição de 30,0 mg. $\mathrm{L}^{-1}$ de $\mathrm{Al}^{3+}$ à solução nutriente conduz à diminuição de todos os parâmetros agronômicos avaliados com perdas de rendimento em cultivos com a maior concentração avaliada. A população de André da Rocha foi a mais tolerante ao alumínio, enquanto que Bom Jardim da Serra foi a mais sensível. A concentração de alumínio não influenciou no rendimento de extração, assim como no teor dos componentes principais nos óleos. A concentração de flavonoides aumentou significativamente nas populações tolerantes ao alumínio, indicando uma relação entre a tolerância ao $\mathrm{Al}^{3+}$ e a produção de flavonoides, o que pode ser interessante do ponto de vista medicinal.
\end{abstract}

Palavras-chave: tolerância ao alumínio, hidroponia, plantas medicinais, flavonoides. 


\section{Introduction}

The use of plants with pharmaceutical properties has received increased interest nowadays from both homeopathic and allopathic branches. Besides, these medicine plants play an important role in public health, especially in developing countries. Cunila galioides Benth. (Lamiaceae), popularly known as "poejo", is a naturally occurring medicinal and aromatic plant native from south Brazil (Bordignon et al., 2003) and three chemotypes (CT) have been ascribed in the literature, CT-citral, CT-ocimene and CT-menthene (Echeverrigaray et al., 2003).

Places where poejo plants are found spontaneously growing are characterised by high altitudes with mild annual temperatures, between 15 and $16^{\circ} \mathrm{C}$, pluviometric precipitation in the range of 1,500 and $2,000 \mathrm{~mm}$ and acid grounds with $\mathrm{pH}$ between 4.5 to 5.5 and high contents of $\mathrm{Al}^{3+}$ toxic (Veloso et al., 2000). One may emphasize that toxicity by aluminum is considered the main factor for abiotic stressing grounds with low pH (Tolrá et al., 2005) and aluminum and $\mathrm{pH}$ are the best predictors of species density (Amorim and Batalha, 2008).

According to Barceló and Poschenrieder (2002), flavonoids exudation from roots is one of the resistance mechanisms of various vegetable species against aluminum from the ground, through the formation of an aluminum complex to diminish the metal toxic effect.

It is known that flavonoids possess several properties and represent one of the most important chemical classes of secondary metabolites, and are structurally diversified among products of vegetable origin and widely distributed (Taylor and Grotewold, 2005). This structural diversification reflects in a great degree of genetic polymorphism, which leads to the production of specific flavonoids as a consequence of different environmental stimulations (Sosa et al., 2005). Ali et al. (2008) studied the role of brassinosteroids in the amelioration of aluminum stress through the antioxidant system and concluded that the high level of proline in association with the antioxidant system, at least in part, was responsible for the perfection of $\mathrm{Al}$ stress in Vigna radiata seedlings.

According to Bordignon et al. (2003), flavonoids of the type free flavones and flavonones were observed in significant amounts in the species Cunila incana, $C$. angustifolia and $C$. incisa and, in lower amount in the species of $C$. fasciculata and $C$. microscephala. The presence of flavonoids in Cunila galioides species has not been reported in the literature yet.

In this context, the main objective of this work is to study the influence of different contents of aluminum on the hydroponics cultivation of three chemotypes of poejo aiming at elucidating the behaviour of such chemotypes for future applications in the area of medicinal plants. To this end, flavonoids content, yield of extract and its chemical profile, calcium and aluminum concentrations in the vegetable tissue, aerial dry matter, dry root matter, root length and root score were all evaluated.

\section{Material and Methods}

\subsection{Plant material}

In this work, three chemotypes of poejo (Cunila galioides Benth.) were studied: from André da Rocha (CT-citral, AR), Santa Lúcia (CT-menthene, SL) and from Bom Jardim da Serra (CT-ocimene, BJ). Plant samples $(15 \mathrm{~cm}$ mean height, around 45-days age) used in the investigation were produced from cuttings in carbonised shell rice substrate under intermittent nebulisation.

\subsection{Growth conditions}

The experiments were conducted in a greenhouse during winter, using a hydroponics system. Aeration was performed by an air compressor, with the help of plastic tubes directly inside the solution, next to each plant sample. The nutrient solution was replaced every week and the $\mathrm{pH}$ was adjusted every day and kept at $4.0 \pm 0.2$ with the addition of $\mathrm{HCl}$ or $\mathrm{NaOH}$.

Considering the different needs of the plant along the growing process, during the first 15 days after planting (experiment installation), plants received a diluted, onefourth concentration of nutrient solution and in the following 15 days, a half concentration of the nutrient solution, after which they were submitted to the treatment for 60 days using full concentration of nutrient solution. The nutrient solution utilised was that proposed by Waard (1969), shown in Table 1, modified with regard to P concentration, reduced to $1.5 \mathrm{mg} . \mathrm{L}^{-1}$ to prevent aluminum precipitation (Veloso et al., 2000).

Treatment experiments were conducted for aluminum concentrations of 0 (control), 7.5, 15.0 and $30 \mathrm{mg} . \mathrm{L}^{-1}$, added as $\mathrm{AlCl}_{3} \cdot 6 \mathrm{H}_{2} \mathrm{O}$, applied to four samples consisting of three plant samples for each of the three poejo chemotypes (i.e., twelve plant samples for each chemotype), randomly distributed in each pipe, $15 \mathrm{~cm}$ separated.

\subsection{Instrumentation}

The extraction of relatively volatile matter and chemical characterisation of the extract obtained regarding major components were carried out according to the procedure reported by Santos et al. (2004). Briefly, the extraction of $1 \mathrm{~g}$ of dried leaves of the three chemotypes was performed through supercritical $\mathrm{CO}_{2}$ using an HP 7680T extraction

Table 1. Composition of the nutrient solution, modified from Waard (1969).

\begin{tabular}{cccc}
\hline Nutrient & $\begin{array}{c}\text { Concentration } \\
\left(\mathbf{m g . L} \mathbf{L}^{-\mathbf{1}}\right)\end{array}$ & Nutrient & $\begin{array}{c}\text { Concentration } \\
\left(\mathbf{m g . L} \mathbf{L}^{-1}\right)\end{array}$ \\
\hline $\mathrm{N}^{-\mathrm{NO}_{3}{ }^{-}}$ & 80.50 & $\mathrm{~B}$ & 0.50 \\
$\mathrm{~N}^{-\mathrm{NH}_{4}^{+}}$ & 10.50 & $\mathrm{Cu}$ & 0.06 \\
$\mathrm{P}$ & 1.50 & $\mathrm{Fe}$ & 5.00 \\
$\mathrm{~K}$ & 39.00 & $\mathrm{Mn}$ & 1.00 \\
$\mathrm{Mg}$ & 24.00 & $\mathrm{Mo}$ & 0.03 \\
$\mathrm{Ca}$ & 39.90 & $\mathrm{Zn}$ & 0.10 \\
$\mathrm{~S}$ & 32.00 & & \\
\hline
\end{tabular}


apparatus, adopting the following parameters: 30 minutes extraction time, $60^{\circ} \mathrm{C}$, pressure of $10 \mathrm{MPa}, \mathrm{CO}_{2}$ flow rate of $1.0 \mathrm{~mL} / \mathrm{min}$. Here, the extract yield is defined as the weight percentage of the oil extracted with respect to the initial charge of the raw material in the extractor (extract/ raw material, wt/wt).

The extracts were analysed with a gas-chromatograph coupled to a mass spectrometric detector (HP 6890/ MSD 5973), using a capillary column HP - Innovax DB$5, \mathrm{H}_{2}(34 \mathrm{KPa})$ as carrier gas, injection in the split mode (ratio 1:50), injection volume of $1 \times 10^{-9} \mathrm{~m}^{3}$ diluted in $1 \mathrm{~mL}$ of n-hexane. The following chromatographic conditions were used: column temperature $60{ }^{\circ} \mathrm{C}$ (8 minutes), 60$180{ }^{\circ} \mathrm{C}\left(3{ }^{\circ} \mathrm{C} / \mathrm{min}\right), 180-230^{\circ} \mathrm{C}\left(20^{\circ} \mathrm{C} / \mathrm{min}\right), 230^{\circ} \mathrm{C}$ (20 minutes); interface $180^{\circ} \mathrm{C}$ (Echeverrygaray et al., 2003). Thedentification of compounds was made by comparing the mass spectra obtained with those from the Wiley library (Wiley 275) and literature data (Echeverrigaray et al., 2003). The content of the major components of each extract is expressed as peak area percent.

The extraction of flavonoids was carried out using $2 \mathrm{~g}$ of dried and crushed leaves through hydroalcoholic distillation under total reflux during 30 minutes using a solution of $100 \mathrm{~mL}$ of ethanol $(40 \%, \mathrm{v} / \mathrm{v})$; the resultant solution was then hot filtered. For the quantification of total flavonoids, the procedure described by Marcucci et al. (2001) was followed, which is based on the complex formed between aluminum and flavonoids in alcoholic medium, with subsequent spectrophotometric analysis at $418 \mathrm{~nm}$. Concentration of flavonoids was then calculated by Equation 1 .

$\mathrm{C}=\frac{\mathrm{A} \times \mathrm{DF}}{\mathrm{m} \times \mathrm{Eo}}$

where $\mathrm{C}$ stands for the flavonoids concentration, expressed as grams of rutin per $100 \mathrm{~g}$ de dried vegetable extract (wt \%), A denotes the absorbance difference between treated and compensation solutions, DF is the dilution factor (1250), m denotes the amount ( $\mathrm{g}$ ) of sample used and Eo is the specific absorbance coefficient (315) of the rutin-aluminum complex, determined by the ratio between the absorbance of the complex and the concentration of the rutin standard. The concentration of $\mathrm{Al}$ and $\mathrm{Ca}$ in the vegetable tissue was determined by Flame Atomic Absorption Spectrometry (Spectra A 250 Plus - Variam), according to Standard Methods $19^{\text {th }}$ Edition (APHA, 1995).

Experimental data were submitted to statistical variance analysis (ANOVA) and also with regard to mean values (Tukey test, 5\%) using the Software Statistica ${ }^{\circledR} 6.0$ (Statsoft Inc.).

Regression analyses and adjustment of equations had been carried out using Microsoft Excel software.

\section{Results}

In general, the variance analysis performed for the four agronomic parameters evaluated revealed the occurrence of significant statistical differences for aluminum concentration, with the exception of dry root matter $(1.28,1.29$ and $1.38 \mathrm{~g} / \mathrm{plant}$ for the chemotypes CT-ocimene, CT-menthene and CT-citral, respectively). In cases where no significant statistical differences were verified for the chemotypes, experimental data were treated and present for mixed populations.

The increasing of the aluminum concentration in nutrient solution caused a clear decrease in the amount of dry root matter.

Related to aerial dry matter for each chemotype, the best performance of CT-citral (5.11 g/plant - AR population) was observed and for the root score, CT-cimene was statistically inferior, thus indicating the existence of genetic differences for these parameters.

A polynomial curve of yield reduction of aerial dry matter and root score was observed, with significant difference at the maximum aluminum dosage $\left(30 \mathrm{mg} . \mathrm{L}^{-1}\right)$ (Figure 1).

The highest values of root length were found for CT-citral chemotype for all aluminum concentrations, especially for higher $\mathrm{Al}$ dosages; however, reductions for all chemotypes were observed, mainly for the BJ population (CT-ocimene chemotype), indicating that this population is more sensitive to stresses caused by aluminum (Table 2).

The average concentrations of $\mathrm{Al}$ and $\mathrm{Ca}$ present in the vegetable tissue of the three populations are shown in Figure 2. The amount of $\mathrm{Al}$ in the vegetable tissue
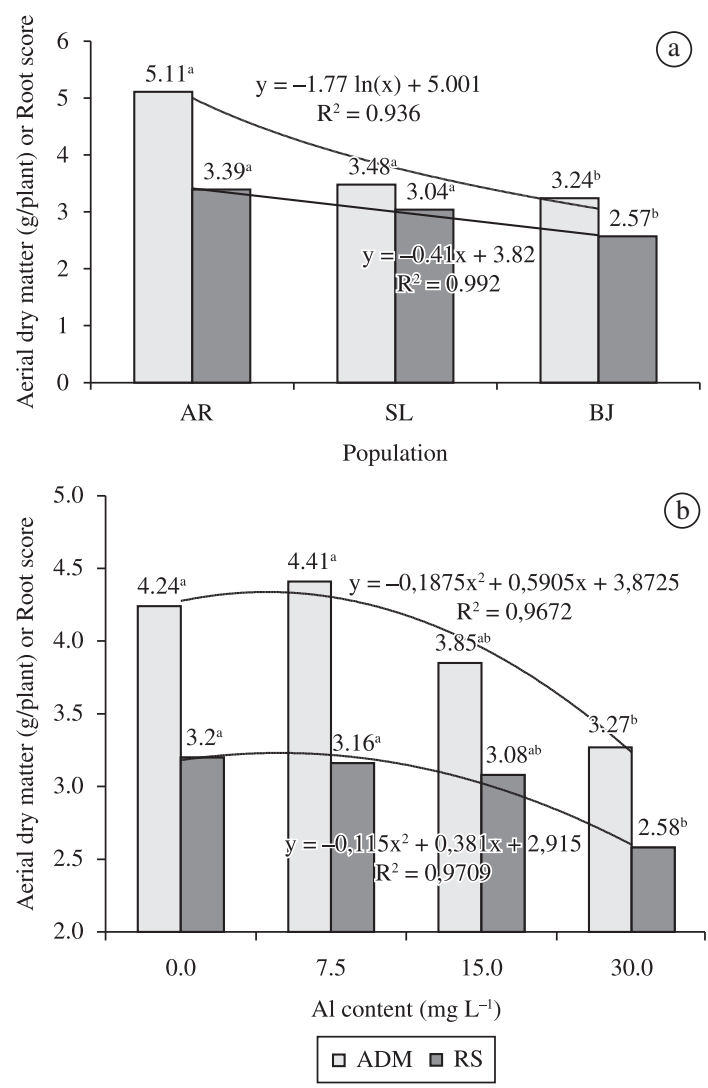

Figure 1. Average values of aerial dry matter (ADM) and root score (RS) for (a) the poejo populations and (b) different levels aluminum concentration in the nutrient solution. 
continuously rises with increasing aluminum concentration in the nutrient solution, up to approximately three times compared to the absence of aluminum, whereas the opposite trend is noticed for $\mathrm{Ca}$.

The highest average extraction yield was obtained for the Santa Lúcia population $(0.6 \%)$, followed by André da Rocha $(0.44 \%)$ and Bom Jardim da Serra $(0.08 \%)$. The treatment with aluminum did not influence the extraction yield as well as the content of major components in the oils and no interaction between $\mathrm{Al}$ concentration and population was observed. Six major components were identified in the three poejo populations: citral (neral + geranial) in André da Rocha (86\%), trans-b-ocimene and ledene in Bom Jardim da Serra (79\%) and 1,3,8-menthatriene, 1,5,8-p-menthatriene and trans-p-2,8-manthatriene-1-ol in Santa Lúcia (83\%).

Regarding the flavonoid content, the interaction between population and aluminum concentration was observed (Table 3). For the André da Rocha and Santa Lúcia populations, the amount of flavonoids increases with increasing $\mathrm{Al}$ concentration in the nutrient solution, with significant amounts produced for the highest $\mathrm{Al}$ concentration value. It can also be noticed from Table 3 that the André da Rocha population showed the highest flavonoid production, but the greatest flavonoid increment was verified for the Santa Lúcia population, from 0.30 to $0.40 \mathrm{~g}$ rutin/ $100 \mathrm{~g}$ of dried vegetable material. For the Bom Jardim da Serra population, no significant statistical differences were observed for the treatments.

Figure 3 shows that the production of flavonoids is inversely related to the root biomass production. Together with a reduction in the dry root matter, an increase in flavonoids production is also observed in response to a stress situation.

Concerning the relationship between flavonoid production and tolerance, one can see from the comparison of data presented in Tables 2 and 3 that the population of Bom Jardim da Serra showed a reduction in the root length with increasing $\mathrm{Al}$ concentration in the nutrient solution, even for the lowest value, while no statistical differences were found regarding flavonoids content. For the other populations, an increase in the flavonoids production was observed with consequent less damage to the root system, and statistically lower values only for the highest concentration of $\mathrm{Al}$ in the nutrient solution.

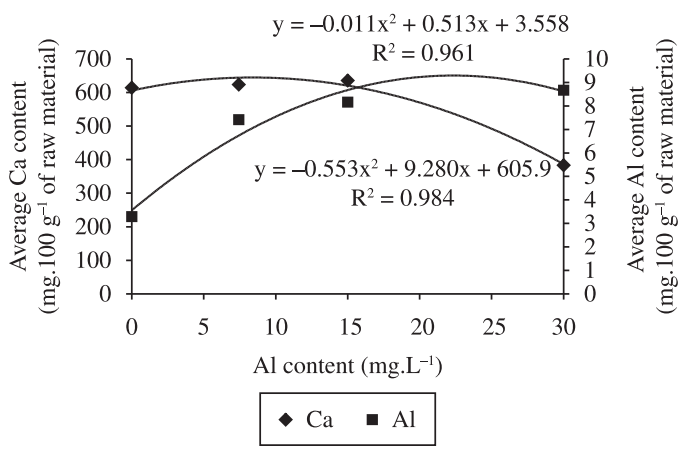

Figure 2. Average concentration of calcium and aluminum in the vegetable tissue of the three poejo populations ( $C$ unila galioides Benth.) submitted to different levels of aluminum concentration in the nutrient solution. Continuous lines are just to improve visualization.

Table 2. Effect of the cross interaction between aluminum content in the nutrient solution and population on the root length of poejo (Cunila galioides Benth.)*.

\begin{tabular}{|c|c|c|c|c|}
\hline \multirow{2}{*}{ Chemotype } & \multicolumn{4}{|c|}{ Root length (cm) } \\
\hline & Al/0 mg.L $\mathrm{L}^{-1}$ & Al/7.5 mg.L $\mathrm{L}^{-1}$ & Al/15 mg.L $\mathrm{L}^{-1}$ & Al/30 mg.L $\mathrm{L}^{-1}$ \\
\hline Andre da Rocha (CT-citral) & $24.95^{\mathrm{aA}}$ & $21.99^{\mathrm{aAB}}$ & $23.49^{\mathrm{aAB}}$ & $21.04^{\mathrm{aB}}$ \\
\hline Bom Jardim da Serra (CT-ocimene) & $23.45^{\mathrm{abA}}$ & $18.41^{\mathrm{bB}}$ & $16.07^{\mathrm{bB}}$ & $15.41^{\mathrm{bB}}$ \\
\hline Santa Lucia (CT-menthene) & $20.91^{\mathrm{bA}}$ & $19.41^{\mathrm{abA}}$ & $18.58^{\mathrm{bAB}}$ & $15.99^{\mathrm{bB}}$ \\
\hline
\end{tabular}

*Different letters mean significant difference at $95 \%$ (Tukey test $-\mathrm{p}<0.05$ ), comparison being made between lower case letters in columns with capital letters in rows.

Table 3. Average content of flavonoids (grams of rutin/100 g of dried vegetable material) in the three populations of poejo (Cunila galioides Benth.) submitted to different levels of aluminum concentration in the nutrient solution*.

\begin{tabular}{llllll}
\hline \multirow{2}{*}{ Population $^{\dagger}$} & \multicolumn{3}{c}{ Concentration of Al in the nutrient solution $\left(\mathbf{m g . L}^{\mathbf{- 1}}\right)$} & \multirow{2}{*}{ Mean } \\
\cline { 2 - 5 } & $\mathbf{0}$ & $\mathbf{7 . 5}$ & $\mathbf{1 5 . 0}$ & $\mathbf{3 0 . 0}$ & $0.37^{\mathrm{a}}$ \\
$\mathrm{AR}$ & $0.35^{\mathrm{aB}}$ & $0.37^{\mathrm{aAB}}$ & $0.37^{\mathrm{aAB}}$ & $0.40^{\mathrm{aA}}$ & $0.34^{\mathrm{b}}$ \\
$\mathrm{BJ}$ & $0.32^{\mathrm{abA}}$ & $0.33^{\mathrm{bA}}$ & $0.36^{\mathrm{aA}}$ & $0.35^{\mathrm{bA}}$ & $0.34^{\mathrm{b}}$ \\
SL & $0.30^{\mathrm{bC}}$ & $0.31^{\mathrm{bBC}}$ & $0.34^{\mathrm{aB}}$ & $0.40^{\mathrm{aA}}$ & - \\
Mean & $0.32^{\mathrm{C}}$ & $0.34^{\mathrm{BC}}$ & $0.35^{\mathrm{B}}$ & $0.39^{\mathrm{A}}$ & - \\
\hline
\end{tabular}

*Different letters mean significant difference at $95 \%$ (Tukey test - $\mathrm{p}<0.05$ ), comparison being made between lower case letters in columns with capital letters in rows. ${ }^{\dagger} \mathrm{AR}$ - André da Rocha; BJ - Bom Jardim da Serra; SL - Santa Lúcia. 


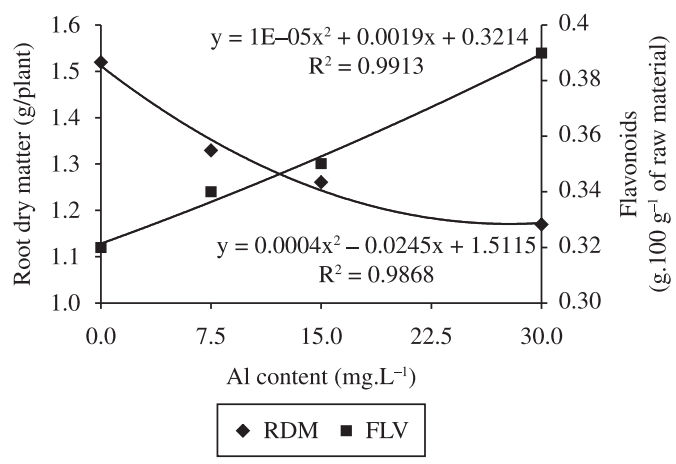

Figure 3. Relationship between average content of flavonoids (FLV) and dry root matter (RDM) in the three populations of poejo (Cunila galioides Benth.) submitted to different levels of aluminum concentration in the nutrient solution.

\section{Discussion}

Differences related to tolerance and susceptibility to aluminum are common among plants of the same species and are attributed to genetic factors (Tang et al., 2002). According to Tang et al. (2003), genotypes more tolerant to aluminum can proliferate more plant root and also produce higher yields in the aerial part due to the ability of searching for water and nutrients.

Significant differences verified for the root length between CT-citral and the other chemotypes may be explained by the greater root thickness. The increase of root thickness is mentioned by some authors as a characteristic symptom of plants susceptible to aluminum (Veloso et al., 2000; Barceló and Poschenrieder, 2002).

According to the literature, the root system is a relevant parameter for the selection of genotypes tolerant to aluminum since this is the most affected part of the plant when submitted to this kind of stress. In fact, the inhibition in the root production is considered the basic toxic effect provoked by aluminum in plants Mazzocato et al., 2002). Silva et al. (2010) showed that Al negatively interferes with $\mathrm{P}, \mathrm{Mg}$ and $\mathrm{K}$ in wheat and $\mathrm{Al}$ interactions with some nutrients depend on the level of plant tolerance. Reported data by the authors also provide support to the hypothesis that endodermis differentiation may be stimulated limiting $\mathrm{Al}$ accumulation/allocation in roots of the tolerant wheat landrace.

Though the antagonist and competitive effects between $\mathrm{Al}$ and $\mathrm{Ca}$ have been reported in the literature (Echart and Cavalli-Molina, 2001), in this work, only for the highest $\mathrm{Al}$ concentration in the nutrient solution was a significant decrease in the $\mathrm{Ca}$ content in the vegetable tissue observed, lower than $400 \mathrm{mg} / 100 \mathrm{~g}$ of tissue (Figure 2). Similar results were found by Mendonça et al. (2003) when working with rice, with a reduction of $\mathrm{Ca}$ content in the aerial part of tolerant cultivars for the highest aluminum concentration.

Important differences in the yield and chemical profile of the extract obtained for the three populations studied were observed. Similar results in terms of extraction yield and chemical composition were found by Santos et al. (2004) for the supercritical $\mathrm{CO}_{2}$ extraction of poejo from the André da Rocha population.

Differences in the content of oil extracted among populations, chemotypes or botanical varieties belonging to the same species are observed in many plants of Lamiaceae family and are genetically determined mainly by the presence in greater or lower amounts of specialised secreting structures, such as glandular trichomes, characteristic of this family (Corsi and Bottega, 1999).

The method employed for the extraction may affect the yield obtained. For instance, Fracaro et al. (2002) applied the hydrodistillation for the extraction of essential oil from distinct populations of poejo and observed superior results when compared with the extraction using supercritical $\mathrm{CO}_{2}$ and also that the yield obtained for the André da Rocha population was greater than that found for the Santa Lúcia population, different from that verified in this work.

Echeverrigaray et al. (2003) argued that geographical distribution of the oil chemotypes can be explained as a result of localised inbreeding effects, associated with low levels of gene flow through the populations and a low incidence of recessive gene expression. It is also likely that a wide variation in essential oil composition may be ecologically advantageous in protecting plants against pathogens or climatic conditions.

Differences found in the flavonoid production for the same species are attributed to genetic factors, while quantitative and qualitative variations among populations may be imposed by the different ecological role of these compounds, produced in response to distinct environmental conditions (Sosa et al., 2005).

Tolrá et al. (2005), in cultivating Rumex acetosa L., with Al-containing nutrient solutions, observed the production of high contents of flavonoids in the aerial part of the plants. The authors suggested that the phenolic compounds are responsible for the plant tolerance to high concentrations of $\mathrm{Al}$ in the vegetable tissue.

According to Barceló and Poschenrieder (2002), the production of flavonoids or increase in the production of this secondary metabolite under stress conditions, may explain the tolerance of some vegetable species to aluminum. Consequently, two strategies may be adopted by the plant, represented by two distinct classes. The first comprises the inactivation of $\mathrm{Al}$ outside the plant with the flavonoids being exuded and acting as quelant agents. The second class of tolerance mechanisms is neutralisation inside the plant with complexation and inactivation of $\mathrm{Al}$ in the cytosol or vacuoles (Echart and Cavalli-Molina, 2001). In this aspect, several authors have highlighted the role of flavonoids as a defense mechanism of the plants and that environmental factors are involved in the synthesis of these metabolites (Sosa et al., 2005; Taylor and Grotewold, 2005).

These results suggest that aluminum induces the production of flavonoids, hence conferring tolerance to the plants under stress conditions. In this respect, Suzuki et al. (2005) observed an increase in the flavonoids content in 
tartary buckwheat [Fagopyrum tataricum (L.) Gaertn], when submitted to stress conditions (UV radiation and desiccation), suggesting that flavonoids might be considered as starters of the plant defense system for some species. The identified presence and quantification of flavonoids in vegetable species may be useful in plant selection or breeding, being indicative of tolerant genotypes, and so helping the understanding of the resistance mechanism in plants submitted to aluminum stress.

\section{Conclusions}

The aluminum concentration did not influence the extraction yield as well as the content of major components in the oils, but affected negatively the agronomic parameters evaluated, with losses in the cultivation yield for the greatest concentration studied. However, the concentration of flavonoids increased significantly for the populations tolerant to aluminum concentration in the nutrient solution, thus showing a relationship between tolerance and flavonoids production, which may be an interesting characteristic from the medicinal point of view.

Acknowledgements - The authors wish to acknowledge CNPq and FAPERGS for the financial support and scholarships. The authors would also like to thank the Universidade de Caxias do Sul-RS, URI-Campus de Erechim-RS and the Secretaria de Ciência e Tecnologia-RS (PIT- Norte).

\section{References}

ALI, B., HASAN, SA., HAYAT, S., HAYAT, Q., YADAV, S., FARIDUDDIN, Q. and AHMAD, A., 2008. A role for brassinosteroids in the amelioration of aluminium stress through antioxidant system in mung bean (Vigna radiata L. Wilczek). Environmental and Experimental Botany, vol. 62, no. 2, p. 153159. http://dx.doi.org/10.1016/j.envexpbot.2007.07.014

American Public Health Association - APHA, 1995. Standard Methods for the Examination of Water and Waste Water. 19nd ed. Washington: APHA.

AMORIM, PK. and BATALHA, MA., 2008. Soil chemical factors and grassland species density in Emas National Park (central Brazil). Brazilian Journal of Biology, vol. 68, no. 2, p. 279-285. http://dx.doi.org/10.1590/S1519-69842008000200008

BARCELÓ, J. and POSCHENRIEDER, C., 2002. Fast root growth responses, root exudates, and internal detoxification as clues to the mechanisms of aluminum toxicity and resistance: a review. Environmental and Experimental Botany, vol. 48, no. 1, p. 75-92. http://dx.doi.org/10.1016/S0098-8472(02)00013-8

BORDIGNON, SAL., MONTANHA, JA. and SCHENKEL, EP., 2003. Flavones and flavonones from South America species (Lamiaceae). Biochemical Systematics and Ecology, vol. 31, no 1, p. 785-788.

CORSI, G. and BOTTEGA, S., 1999. Glandular hairs of Salvia officinalis: new data on morphology, localization and histochemistry in relation to function. Annals of Botany, vol. 84, no. 5, p. 657664. http://dx.doi.org/10.1006/anbo.1999.0961
ECHART, CL. and CAVALLI-MOLINA, S., 2001. Aluminum phytotoxicity: effects, tolerance mechanisms and its genetic control. Ciência Rural, vol. 31, no. 3, p. 531-541. http://dx.doi. org/10.1590/S0103-84782001000300030

ECHEVERRIGARAY, S., FRACARO, F., SANTOS, AC., PAROUL, N., WASUM, R. and SERAFINI, LA., 2003. Essential oil composition of South Brazilian populations of Cunila galioides Benth. and its relation with the geographic distribution. Biochemical Systematics and Ecology, vol. 31, no. 5, p. 467-475. http://dx.doi. org/10.1016/S0305-1978(02)00175-8

FRACARO, F., SERAFINI, LA., SANTOS, ACA., PAROUL, N. and ECHEVERRIGARAY, S., 2002. Analysis of the essential oil composition of Cunila galioides Benth. Journal of Essential Oil Research, vol. 14, no. 1, p. 336-338.

MARCUCCI, MC., FERRERES, F., GARCÍA-VIGUERA, C., BANKOVA, VS., CASTRO, SL., DANTAS, AP., VALENTE, PHM. and PAULINO, N., 2001. Phenolic compounds from Brazilian propolis with pharmacological activities. Journal of Ethnopharmacology, vol. 74, no. 2, p. 105-112. http://dx.doi. org/10.1016/S0378-8741(00)00326-3

MAZZOCATO, AC., ROCHA, PSG., SERENO, MJCM., BOHNEN, H., GRONGO, V. and BARBOSA NETO, JF., 2002. Aluminum tolerance in maize plants. Ciência Rural, vol. 32, no. 1, p. 19-24.

MENDONÇA, RJ., CAMBRAIA, J., OLIVEIRA, JA. and OLIVA, MA., 2003. Aluminum effects on the uptake and utilization of macronutrients in two rice cultivars. Pesquisa Agropecuária Brasileira, vol. 38, no. 7, p. 843-848.

SANTOS, ACA., PAULETTI, GF., ROTA, LD., PANSERA, MR. and SERAFINI, LA., 2004. Supercritical $\mathrm{CO}_{2}$ extraction of Cunila galioides essential oil. In Proceedings of the V Brazilian Meeting on Supercritical Fluids, 2004. Florianópolis: UFSC.

SILVA, S., PINTO-CARNIDE, O., MARTINS-LOPES, P., MATOS, M., GUEDES-PINTO, H. and SANTOS, C., 2010. Differential aluminium changes on nutrient accumulation and root differentiation in an $\mathrm{Al}$ sensitive vs. tolerant wheat. Environmental and Experimental Botany, vol. 68, no. 1, p. 91-98. http://dx.doi. org/10.1016/j.envexpbot.2009.10.005

SOSA, T., ALÍAS, JC., ESCUDERO, JC. and CHAVES, N., 2005. Interpopulational variation in the flavonoid composition of Cistus ladanifer L. exudate. Biochemical Systematics and Ecology, vol. 33, no. 4, p. 353-364. http://dx.doi.org/10.1016/j.bse.2004.10.011

SUZUKI, T., HONDA, Y. and MUKASA, Y., 2005. Effects of UV-B radiation, cold and desiccation stress on rutin concentration and rutin glucosidase activity in tartary buckwheat (Fagopyrum tataricum) leaves. Plant Science, vol. 168, no. 5, p. 1303-1307. http://dx.doi.org/10.1016/j.plantsci.2005.01.007

TANG, C., RENGEL, Z., ABRECHT, D. and TENNANT, D., 2002. Aluminum-tolerant wheat uses more water and yields higher than aluminum-sensitive one a sandy soil with subsurface acidity. Field Crops Research, vol. 78, no. 1, p. 93-103. http:// dx.doi.org/10.1016/S0378-4290(02)00105-3

TANG, C., RENGEL, Z., DIATLOFF, E. and GAZEY, C., 2003. Responses of wheat and the barley to liming on a sandy soil with subsoil acidity. Field Crops Research, vol. 80, no. 3, p. 235-244. http://dx.doi.org/10.1016/S0378-4290(02)00192-2 
TAYLOR, LP. and GROTEWOLD, E., 2005. Flavonoids as developmental regulators. Current Opinion in Plant Biology, vol. 8, no. 3, p. 317-323. PMid:15860429. http://dx.doi.org/10.1016/j. pbi.2005.03.005

TOLRÁ, RP., POSCHENRIELDER, C., LUPPI, B. and BARCELÓ, J., 2005. Aluminum-induced changes in the profiles of both organic acids and phenolic substances underlie $\mathrm{Al}$ tolerance in Rumex acetosa L. Environmental and Experimental Botany, vol. 54, no. 4, p. 231-238, 2005.

VELOSO, CAC., MALAVOLTA, E., MURAOKA, T. and CARVALHO, EJM., 2000. Aluminum and calcium absorption by black pepper seedlings. Scientia Agricola, vol. 57, no. 1, p. 141-145.

WAARD, PWF., 1969. Foliar diagnosis, nutrition and yield stability of black pepper (Piper nigrum, L.). In WAARD, PWF. Sarawak. Amsterdam: Royal Tropical Institute. 149 p. (Communication, 58). 
